Revista de Literatura, História e Memória

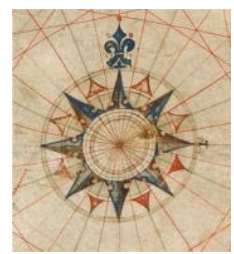

Dossiê: Manifestações de re-existência: a literatura em tempos de repressão

ISSN 1983-1498

VOL. 16 - No 27 - 2020

U N I O E S T E / CA S C A V E L - p. 12-27

\title{
GRITOS E SANGUE ENTRE PAREDES MUDAS: MEMÓRIA E SILENCIAMENTO DE LOCAIS TRAUMÁTICOS
}

\author{
Screams and blood between silent walls: memory and \\ silencing of traumatic places
}

\author{
Anairan Jeronimo ${ }^{1}$ \\ Carlos Henrique lopes de Almeida ${ }^{2}$
}

RESUMO: Neste artigo analisamos o silenciamento que recai sobre a memória de locais traumáticos, em especial as representações dos locais de tortura perpetrada pelo Estado, reproduzidas em narrativas que evocam as lembranças de contextos ditatoriais no Brasil e na Argentina. O objetivo é refletir sobre as forças sociais que conduzem ao esquecimento desses locais e apontar formas de resistência a esse cenário. Tecemos uma leitura dos contos A mancha (2004), de Luís Fernando Veríssimo, e "A hospedaria" (2017), de Mariana Enríquez, para compreender como o contato com os locais traumáticos evoca memórias torturadas e como a literatura assume uma posição ética de resistência ao silenciamento dessas memórias.

PALAVRAS-CHAVE: Locais traumáticos; Memória; Silenciamento; Resistência.

ABSTRACT: In this article we analyze the silencing that affects the memory of traumatic places, in particular the places of torture perpetrated by the State, reproduced in narratives that evoke the memories of dictatorial contexts in Brazil and Argentina. The objective is to reflect on the social forces that lead to the forgetfulness of these places and point out ways to resist this scenario. We did a reading of the stories A mancha (2004), by Luís Fernando Veríssimo, and "A hospedaria" (2017), by Mariana Enríquez, to understand how contact with traumatic places evokes tortured memories and how literature assumes an ethical position of resistance to silencing these memories.

KEY WORDS: Traumatic places; Memory; Silencing; Resistence.

1 PAI, AFASTA DE MIM ESSE CÁLICE

Pai, afasta de mim esse cálice De vinho tinto de sangue ${ }^{3}$

"Cale-se!" O verbo no imperativo, que emerge da repetição em coro do substantivo “cálice” no refrão de Chico Buarque e Gilberto Gil (1978), representa uma violenta repressão

\footnotetext{
${ }^{1}$ Professora de Língua Portuguesa e Literatura do Instituto Federal do Maranhão. Doutoranda do Programa de Pós Graduação em Estudos Literários da UFPA. Mestra em Linguística pela UFC.Membro do Grupo de Estudos em Fronteiras Literárias (IFMA), do Grupo de Estudos Narrares (UFPA) e do Grupo de Estudos em Literatura, Alteridade e Decolonialidade (UFMA).

${ }^{2}$ Prefessor de Lingua adicional e literatura da América Latina no Ciclo comum do estudos da UNILA. Atua no Programa de pós-graduação em letras (PPGL) da Universidade Federal do Pará. Lider do grupo de pesquisa Literatura, educação, sociedade e cultura.

${ }^{3}$ Os nomes dados às seções do trabalho, bem como as epígrafes de cada parte, são recortes da música "Cálice", de Chico Buarque e Gilberto Gil (1978).
} 
à memória de uma ditadura civil-militar: a ordem para não testemunhar. Calar é emudecer os gritos e esconder o sangue derramado dentro dos locais de tortura perpetrada pelo Estado. É negar a existência desses locais e silenciar a memória do trauma sobrelevada em suas paredes, empreendendo uma força que ambiciona o esquecimento. E não há resistência mais ofensiva ao esquecimento do que a lembrança.

Memória e silenciamento são instâncias que se opõem e se retroalimentam. Estabelecem uma relação de interdependência, cujo cerne é a disputa pelo destino que se dará às marcas históricas da violência. A primeira quer trazer a lembrança à tona e garantir sua ressignificação no fluxo entre o passado e o presente. A segunda quer aniquilá-la, levá-la ao esquecimento apagando seus rastros à medida que o passado se torna mais remoto. Desse modo, "a memória só existe ao lado do esquecimento: um complementa e alimenta outro, um é o fundo sobre o qual o outro se inscreve" (SELIGMANN-SILVA, 2003, p. 53). Essa disputa fica mais acirrada quando o passado de violência faz concorrer discursos que representam os lados opostos da experiência traumática: quem sofreu e quem promoveu. O local traumático atua como um gatilho que traz a evidência desse jogo de inscrições da violência na memória histórica.

Locais traumáticos são lugares revestidos de uma significação simbólica que remete ao trauma e ao sofrimento de um grupo. Enquanto símbolos, perpetuam-se e ressignificam-se historicamente à medida que evocam uma memória de dor, construída a partir da experiência de submissão à violência sofrida pelo grupo. Nos termos de Assmann, esses locais tornam-se “sujeitos, portadores da recordação e possivelmente dotados de uma memória que ultrapassa amplamente a memória dos seres humanos" (ASSMANN, 2011, p. 317). Assim, se a brutalidade cometida ali alcançar o conhecimento público, esses locais serão lidos como uma marca da violência autorizada e consumada pelo Estado em determinado período histórico.

O Departamento de Ordem Política e Social (DOPS), no Brasil, assim como a Escuela de Mecánica de La Armada (ESMA), na Argentina, são exemplos de locais de repressão brutal utilizados pelo Estado para reprimir, com tortura e morte, os presos políticos da ditadura nesses países. Locais como esses, assim como os campos de extermínio europeus, são evidências históricas de atrocidades que "implodem a capacidade humana de apreender e representar" (ASSMANN, 2011, p. 361). Por isso, incide sobre eles uma força de repressão da memória traumática que se processa pelo silenciamento. Essa força se sustenta pela impossibilidade de testemunhar, por parte da vítima; e pelo empenho em calar o testemunho e esterilizar o acontecimento, por parte do Estado. Locais traumáticos são marcados pela impossibilidade de narrar, já que, ainda segundo Assmann, “a narração da história está 
bloqueada pela pressão psicológica do indivíduo ou pelos tabus sociais da comunidade" (ASSMANN, 2011, p. 349).

A força de silenciamento que incide mais imediatamente sobre a memória de um grupo é a psicológica. A princípio, apresenta-se no âmbito pessoal, cingida por uma tensão pretensamente individual, e se traveste na impossibilidade de traduzir o intraduzível. $\mathrm{O}$ trauma está dentro do sujeito como parte construtiva dele próprio, pois atinge seu entendimento de si, do mundo e da realidade em níveis profundos. A lembrança do trauma devolve o sujeito ao passado, deixa-o nu; o passado sempre o alcança despido.

Seligmann-Silva assevera que a história de um trauma é a história de um choque violento, o qual esgota a capacidade de testemunhar, pois representa uma incompatibilidade com o real. Assim, essa "incapacidade de simbolizar o choque - o acaso que surge com a face da morte e do inimaginável - determina a repetição e a constante 'posterioridade', ou seja, a volta aprés-coup da cena" (SELIGMANN-SILVA, 2003, p. 49). Retornar à cena de tortura, então, é o mesmo que revivê-la; é beber novamente o cálice de sangue. Por isso, o fluxo entre o passado e o presente é uma experiência dolorosa a que a vítima é submetida enquanto lida com a lembrança traumática. Ademais, a força psicológica de silenciamento funciona como uma tentativa de preservação da integridade do indivíduo, recobrindo-o com suas vestes. Nesse sentido, a incapacidade de lidar com a lembrança se traduz na impossibilidade de narrar, de testemunhar, ainda que a necessidade de traduzir o intraduzível persista, afinal, há uma "cisão entre a linguagem e o evento" (SELIGMANN-SILVA, 2003, p. 46).

Nesse ínterim, Halbwachs (2003) demonstra que esquecer um período da vida implica esquecer todos aqueles que circundavam a experiência do indivíduo naquele contexto. Silenciar uma memória traumática é, assim, silenciar o grupo do qual o indivíduo fez parte. No caso da violência circunscrita na memória de um coletivo, a lembrança foi forjada no compartilhamento de experiências desse grupo. O cálice contém o sangue de muitos. Além disso, a memória é fragmentária, instituída por meio da justaposição de quadros que integram o passado a um presente que o ressignifica e o reinterpreta. Isso porque "apresenta ao grupo um quadro de si mesma que certamente se desenrola no tempo, já que se trata de seu passado, mas de tal maneira que ele sempre se reconheça nessas imagens sucessivas" (HALBWACHS, 2003, p. 109). A memória coletiva é, portanto, a imersão na linha de pensamento do grupo. Sua conservação implica no resgate e na perenização dessa linha de pensamento, construída a partir de crenças e ideologias que unem formas de pensar o mundo e de agir sobre ele. É sobre esse ponto que incide uma força de silenciamento ainda mais repressiva: a social.

Os locais de tortura, gatilhos da memória de violência, são símbolos de uma tentativa 
brutal de silenciar uma linha de pensamento que se projetava contra o Estado em cenários de ditadura. Se nessa conjuntura o Estado tentou neutralizar um coletivo que o contestava, é porque interessava a quem estava no poder manter-se no poder e conduzir a sociedade a acreditar que qualquer violência cometida em prol da segurança da nação estava justificada. A violência investida ali foi uma tentativa de silenciar a linha de pensamento de um coletivo que subvertia a ordem de calar. De mais a mais, vale destacar que esses locais ancoram múltiplos afetos, porque neles se projetam diferentes perspectivas sobre a violência inscrita em suas paredes. Em torno de sua construção como símbolo aglutinam-se intepretações diversas do que foi esse trauma e de como senti-lo.

Se, por um lado, a lembrança da tortura reacende pelo testemunho de quem a sofreu, por outro ela é silenciada por um projeto histórico de esquecimento dos crimes cometidos por quem tinha interesse em se manter no poder. Ainda assim, o coletivo tem seus interesses regidos e orquestrados pelo Estado, que se utiliza de todos os mecanismos retóricos ao seu alcance para instituir a "verdade sobre os fatos" que lhe convenha. Aí se instaura uma disputa de narrativas, que têm a autoridade do discurso como garantia de manutenção de poder do coletivo que se enuncia. O empenho do Estado é o de desacreditar o testemunho do trauma, desautorizá-lo, reduzi-lo a uma falácia. O faz postulando-se como autoridade, validando seu autoritarismo, instaurando sua verdade própria sobre as evidências. A força de silenciamento alcança a sociedade, porque, em geral, o que lhe resta é interpretar os testemunhos que concorrem pelo modo como a inscrição do lugar traumático será feita na memória nacional. E, nesse campo, entre saber da existência desses locais, mas não como lidar com sua lembrança, a sociedade também os silencia. Não se trata aqui de analisar de quem a sociedade torna-se cúmplice, tampouco colocá-la como algoz. O fato é que, na disputa de poder entre narrativas, o local traumático é uma mancha de violência na memória histórica, e o modo como a sociedade interpreta e reage a esse passado nebuloso é resultado desse jogo discursivo de poder. A força de silenciamento social se empenha em afirmar que o que há no cálice não é sangue. Vinho, talvez. Outra coisa que não sangue. Talvez nem haja um cálice.

Entretanto, como afirma Sarlo, o passado é inevitável; ele "acomete independentemente da vontade e da razão. Sua força não pode ser suprimida senão pela violência, pela ignorância ou pela destruição simbólica e material” (SARLO, 2007, p. 114). Há um cálice de sangue. É sangue. E ele nunca se esvazia. A força de silenciamento social investe brutalmente contra a memória de um coletivo que pretende se manter na obscuridade, mas essa memória conduzida à marginalidade, a que Pollak $(1989$, p. 4) chamou de "memória subterrânea", ainda que silenciada pelo enquadramento histórico, mantém-se em um trabalho 
de subversão no silêncio e sempre aflora em momentos de crise.

O silêncio da memória subterrânea, em vez de conduzi-la ao esquecimento, é uma forma de resistência ao excesso de discursos oficiais, porque o testemunho da violência vai se penetrar em instâncias discursivas mais particulares e ser retomada por narrativas das mais diferentes naturezas, que recontam e reinterpretam o passado sob a ótica do presente em que são enunciadas.

A literatura exerce seu protagonismo entre as narrativas capazes de trazer à superfície o que está no subterrâneo da memória traumática. Se o silenciamento é uma força simbólica que emudece a lembrança, o texto literário potencialmente a reinterpreta. Portanto, esse ensaio toma como plano de fundo duas narrativas importantes para compreender de que modo a escrita literária evidencia o silenciamento dos locais traumáticos no contexto da América Latina.

Do Brasil, Luís Fernando Veríssimo, em seu conto "A mancha" (2004), traz as fissuras da memória de violência sofrida por um homem torturado. Com um protagonista obcecado em reedificar o seu passado demolido pelo esquecimento, o texto retorna aos locais de tortura do Regime Militar e, pelo olhar da vítima, restabelece uma conexão entre passado e presente, como se, para isso, utilizasse os quadros da memória traumática com tijolos para a construção do sujeito torturado. Da Argentina, no conto "A hospedaria", do livro As coisas que perdemos no fogo (2017), Mariana Enríquez demonstra sensivelmente o que seria, para a vítima, a impossibilidade de narrar o trauma. Nessa narrativa, a lembrança da ditadura aparece em assombros, como imagens projetadas em um jogo de luz e sombra, silêncio e bramido. Interessa descortinar nos contos exatamente o desgaste da memória dos sujeitos torturados, compreendê-los enquanto vozes subterrâneas e enquanto desvelamento da memória de violência silenciada pelas ditaduras.

\section{SILÊNCIO NA CIDADE NÃO SE ESCUTA}

Mesmo calada a boca, resta o peito Silêncio na cidade não se escuta

Quando Chico e Gil, nos anos 70, apresentaram "Cálice" ao público, o cenário de censura era tão repressor que toda forma de arte que denunciasse as atrocidades do Regime Militar era uma evidência da mente subversiva de seu autor.

A música traz uma construção metafórica que liga o suplício da vítima torturada pela 
ditadura àquele vivido por Jesus Cristo. E ele o testemunha. Jesus é um símbolo de corpo torturado que os poetas só puderam imprimir na música porque a arte não se dobra ao silenciamento da censura. "Cale-se!" é uma ordem para não testemunhar, mas toda ordem é passível de não ser cumprida. E não há resistência mais ofensiva ao silenciamento do que o testemunho.

De acordo com Seligmann-Silva, devemos "manter o conceito aberto da noção de testemunho: não só aquele que viveu um martírio pode testemunhar; a literatura sempre tem um teor testemunhal" (2003, p. 48). A arte sempre tem um teor testemunhal. E, enquanto narrativa, ela toca experiências que ultrapassam a fronteira do indizível. A arte é o caminho que torna capaz a incapacidade de narrar o trauma. Por essa razão, a música de Chico e Gil pode ser lida nos mais diferentes cenários de autoritarismo. A literatura é a arte do narrar e se apresenta como um relicário de expressão da memória. Além disso, não apenas diz o indizível; ela o traduz. Traduzido, o indizível resiste ao silenciamento. Aliás, Literatura é resistência. É a voz que afirma que mesmo calada a boca, resta o peito, e que o silêncio na cidade se faz ouvir. Então, se a memória traumática impressa nos locais de tortura ditatoriais resiste às forças de silenciamento, a literatura é uma possibilidade de trazer viva a lembrança, traduzir o indizível sobre ela. Para discorrer acerca dessa potência, vejamos o indizível traduzido em "A mancha", de Luís Fenando Veríssimo, e em "A hospedaria”, de Mariana Enríquez.

\subsection{COMO É DIFÍCIL ACORDAR CALADO}

Como é dificil acordar calado Se na calada da noite eu me dano

Alfredo Bosi afirma que "Resistência é um conceito originariamente ético, e não estético. O seu sentido mais profundo apela para a força da vontade que resiste a outra força, exterior ao sujeito. Resistir é opor a força própria à força alheia” (BOSI, 1996, p. 11). O conceito originalmente ético se vê representado em múltiplas formas do fazer estético, em espaços narrativos em que se delineia um cenário de oposição de forças. O conto "A mancha", de Veríssimo, demonstra bem essa disputa. De um lado, a lembrança, enquanto força de resistência, traduz a dificuldade de se acordar calado; do outro, as forças de silenciamento psicológico e social, forças alheias, que atuam contra quem se dana na calada da noite.

Rogério enriqueceu ao retornar do exílio comprando prédios antigos, demolindo-os ou 
reformando-os para revender. Ele lucra com as ruínas de prédios esquecidos. Rogério imergiu em um cotidiano comum, que por muito tempo o manteve distante da memória traumática de tortura que sofreu no Brasil na época da ditadura civil-militar. Rico, casado, uma filha. Tudo dentro da pretensa normalidade. Até que, explorando o potencial lucrativo de certo prédio antigo, reconhece uma mancha de sangue. Seu sangue. Marcado no carpete da sala onde fora torturado no passado. Compra o prédio imediatamente e, a partir daí, conecta-se com as lembranças sombrias daquele lugar, o que fica evidente em um diálogo com Alice, sua esposa:

- Mas eu reconheci a peça. E a mancha está lá, no chão. A mancha do meu sangue.

- Não pode ser.

- [...]. Na peça, só tinha uma cadeira de ferro onde nos botavam e uma espécie de sofá onde eles sentavam. Um sofá mole. Eu te contei. O negro se afundava no sofá. (VERÍSSIMO, 2004, p. 17, grifos nossos)

Rogério tem necessidade de falar, descrever o ambiente de tortura instaurado naquele quarto, verbalizar sua experiência, pois "a narração da experiência está unida ao corpo e a voz, a uma presença real do sujeito na cena do passado (SARLO, 2007, p. 24). A lembrança da dor é uma pulsação amplificada que faz bater, no mesmo ritmo, coração e cordas vocais. A narração atada ao corpo não se contém, pois corpo e narrativa são um só frenesi. Não há narração sem um corpo, e para o sujeito não há como o corpo voltar a ser seu sem que o tenha narrado. A subjetividade do corpo é uma construção narrativa.

Mas Alice não quer ouvir; ela representa a força oposta, o silenciamento social que coloca o testemunho em descrédito contestando a validade da lembrança no empenho de silenciá-la. Para invalidar a lembrança restaurada pelo prédio, Alice invalida o próprio prédio: "Pensa um pouco, Rogério. A peça fica na frente do prédio. Dá para a rua. Você acha que eles iam fazer uma sala de tortura na frente do prédio, para todo o bairro saber?” (VERÍSSIMO, 2004, p. 17). Invalidar o local traumático não quer dizer necessariamente desmenti-lo, mas tirar o seu valor e a sua potência. A exemplo do que ouve no DOPS, adscrito na memória nacional como local de tortura, o silenciamento social não deixa de reconhecer o passado como verdade, mas distancia essa verdade do agora, promovendo uma ruptura entre o passado e o presente. Houve um cálice de sangue; não há mais. Mas, Alice se nega ao reconhecimento do local como verdade, e o faz ficcionalizando o raciocínio de Rogério. Esse é outro mecanismo, ainda mais cruel, da força de silenciamento social. Silenciamento e lembrança são forças opostas e apresentam seus argumentos na disputa de narrativas pela verdade sobre o passado. A lembrança aponta as evidências, já o silenciamento lhes interpreta como ficção, devaneio ou 
loucura. Não. Nunca houve um cálice de sangue!

Alice também representa o silenciamento psicológico. Usa como argumento para o esquecimento o equilíbrio das relações familiares, sempre lembrando Rogério de que é pai e deve manter o passado fora de casa. Lembrar o passado? Não pode ser. Alice é uma peçachave na trama de Veríssimo. Como esposa, representa a autoridade do discurso que o sujeito atribui a quem ele destina seus afetos. Um amigo, um parente e um cônjuge, por exemplo, têm, pela própria natureza da relação construída pelo afeto, a autoridade de dizer o que é bom e o que é ruim para o sujeito. Esse dizer, ainda que carregado de sutilezas, é imperativo e assertivo, pois se fundamenta em um “eu só quero o que é melhor para você". Alice é, portanto, uma autoridade em si mesma. Contudo, "a tortura não abandona o torturado nunca" (ASSMANN, 2011, p. 277). E a descrição da tortura, para Rogério, reforça a autenticidade da lembrança. Ele insiste. E continua escavando o passado à medida que tenta confluir sua memória com a do prédio. Procura, então, descobrir as origens do edifício:

- Fins dos anos 60, começo dos anos 70. A senhora não se lembra de movimento no prédio? Carros chegando. Gritos lá de dentro.

- Gritos?

- Movimento. Carros chegando e saindo.

- Não. Desde que eu me lembro, aquilo só é depósito de lixo.

(VERÍSSIMO, 2004, p. 23, grifos nossos).

Outra vez o personagem se vê diante da força de silenciamento social. Como afirma a personagem senhora mais adiante: “Quem é que se lembra dos anos 70?” (VERÍSSIMO, 2004, p. 23). Rogério se lembra. O lixo depositado ali só poderia ser a violência marcada entre as paredes. Segue a busca. Na tentativa de reconstituir a memória enterrada, reencontra Rubinho:

- É a mesma sala ou não é?

- Não sei. Eu não me lembrava do carpete.

- Olha ali a mancha de sangue.

- Como é que você sabe que é sangue? E que o sangue é seu?

(VERÍSSIMO, 2004, p. 44, grifos nossos).

Para Halbwacks, "no momento em que examina seu passado, o grupo nota que continua o mesmo e toma consciência de sua identidade através do tempo" (HALBWACKS, 2003, p. 108). O grupo é o mesmo porque o passado não muda, muda a perspectiva sobre ele. Rogério e Rubinho são componentes de um grupo sobre o qual nem dimensionam. Quem mais foi torturado pela ditadura? Quantos? Por quê? Incluídos ao grupo dos subversivos à força, ou por convicção, compartilham lembranças traumáticas daquele local e por elas se 
identificam. No entanto, tomado pela impossibilidade de lidar com o trauma, contestando, como Alice, a validade das lembranças de Rogério, Rubinho não suporta segurar o cálice: "Põe tudo abaixo. É a única coisa a fazer com monstruosidades. Pôr abaixo, esquecer e começar tudo de novo. Sem vestígios do passado" (VERÍSSIMO, 2004, p. 50, grifos nossos). Rubinho representa a força de silenciamento psicológica. É o sujeito forçado a silenciar a si mesmo. Por isso, quando interpelado por Rogério quanto à mancha de sangue, a nega. Rogério, porém, persiste na busca, "Porque um edifício fica. Também envelhece e se deteriora, como as pessoas, mas fica. Continua onde estava durante toda a história. Fica para lembrar a história" (VERÍSSIMO, 2004, p. 46, grifos nossos). Fica para lembrar as memórias subterrâneas de um grupo, e desse grupo Rubinho não esquece: “Coitados de nós. Coitados dos quebrados. Eu contei que todos do meu grupo desapareceram? Esses, sim, saíram da história” (Ibidem, p. 47).

Rubinho é uma força dúbia. Enquanto representação é, ao mesmo tempo, silenciamento e resistência. Seu silêncio é uma forma de resistir ao indizível. Isso porque, segundo SarmentoPantoja, a resistência "está no próprio indivíduo, que busca superar seus traumas, suas dificuldades para resistir primeiro em seu interior, para quem sabe ir contra a corrente" (SARMENTO-PANTOJA, 2015, p. 141, grifo do autor). É pelo silêncio que certas vítimas resistem à condição de "sub-homens", pois ele representa uma recusa ao enquadramento da memória a que a história submete os indivíduos (POLLAK, 1989, p. 14). Calar é a estratégia utilizada por Rubinho, a única possível, para resistir às implicações psicológicas que o trauma produz.

- Mas alguma coisa aconteceu. Não só a nós naquela cadeira de ferro. Ao país, a toda uma geração. Foi isso que eu senti quando vi a mancha no chão. Porra! Alguma coisa tinha havido, e deixado uma marca. E esquecer isso era uma forma de traição. (VERÍSSIMO, 2004, p. 48, grifos nossos).

Rogério continua na luta por traduzir o indizível. E revisitando o lugar, buscando evidências da sua experiência traumática, falando da mancha e de como ela ocorreu, extraindo lembranças do esquecimento, é que ele se sente fazendo justiça à memória de um coletivo com o qual compartilha o trauma. Quanto ao prédio, Alice pedia para se desfazer dele; Rubinho, para dinamitá-lo, mas Rogério, opondo a própria força à força alheia, persiste, pois, como afirma Ganegbin (2006, p. 99), é “[...] próprio da experiência traumática essa impossibilidade do esquecimento, essa insistência na repetição".

A insistência na disputa pela narração da lembrança de violência, pela descrição do prédio enquanto um local traumático, é movida pela necessidade de fazer justiça a uma 
memória que Rogério sabia estar condicionada ao esquecimento devido às forças de silenciamento que incidem sobre ela. Mas esse prédio perdido nas ruínas do esquecimento é a prova das práticas criminosas, executadas na clandestinidade, das quais foi vítima. É o lugar de onde se extraiu o sangue para encher o cálice. Uma prova que Rogério só pode validar para si mesmo, porque o prédio nada diz a quem não experienciou o trauma entre suas paredes. Enquanto metáfora, o prédio é o próprio cálice. Representa os inúmeros porões da ditadura civil-militar brasileira, onde sujeitos e memórias foram aniquilados. Para Assmann (2011), enquanto local traumático, o prédio é um sujeito em si, pleno de uma significação que transcende o entendimento humano sobre o trauma.

“Deixa o passado no passado, que é o lugar dele. Ou destrói e constrói outra coisa mais bonita no lugar. Não é o que você faz?" (VERÍSSIMO, 2004, p. 24). Esse é o conselho de Alice e o que pode resumir o trânsito entre passado e presente a que o contato com o prédio submete Rogério. As forças de silenciamento social e psicológica ordenam para não testemunhar. "Calese!" é o que Rogério escuta em toda sua busca pela reconstrução das lembranças traumáticas. E nessa disputa entre memória e silenciamento ele se vê em um entrelugar": "Comprar o passado, renovar, vender e enriquecer mais. Ou comprar o passado, destruir, e pensar no que fazer com o vazio" (VERÍSSIMO, 2004, p. 57). Mas o entrelugar é lugar nenhum. E ele precisa decidir entre dizer o indizível de sua memória subterrânea, ou não dizer mais nada. Rogério, então, afasta o cálice, dinamita o prédio e silencia.

\subsection{QUERO LANÇAR UM GRITO DESUMANO}

Quero lançar um grito desumano Que é a maneira de ser escutado

As coisas que perdemos no fogo (2017), de Mariana Enríquez, é uma coletânea de contos fantásticos, em que transitam o terror, a angústia e a incompletude do narrar que situa a memória traumática da ditadura argentina em um universo grotesco. O conto "A hospedaria" é a narrativa do grito desumano lançado na calada da noite. Aqui, mais uma vez, pressões psicológica e social são interpretadas como forças de silenciamento que coíbem a narração da história.

Florência viaja com a mãe e a irmã para Sanagasta. Uma viagem a contragosto. O pai, político, havia determinado que se afastassem de La Rioja durante as eleições. Sanagasta era

\footnotetext{
${ }^{4}$ Tomemos "entrelugar", em uma perspectiva metafórica, como a posição de conflito entre escolhas opostas; a não resolução do dilema. Que, por ser indecisão, é decisão nenhuma.
} 
provinciana, sem restaurantes, nem um lugar para tomar café, sem muitos atrativos, a não ser a hospedaria, e a mãe "Estava farta da hospedaria [...] Farta de que a única diversão fosse jantar frango ao forno na hospedaria, jogar na roleta e nas maquininhas do cassino da hospedaria, conhecer algum turista europeu na hospedaria” (ENRÍQUEZ, 2017, p. 35). Longe de parecer um local traumático, a hospedaria era um importante ponto de lazer da cidade. Quando chegou, Florência foi logo encontrar Rocío, uma amiga por quem nutria um apreço especial. Rocío estava com raiva, porque seu pai, que trabalhava como guia turístico na hospedaria, fora demitido quando Elena, a proprietária, soube que ele contou a um grupo de turistas que o local havia sido uma escola de polícia trinta anos antes.

- Não quer que os turistas pensem mal, diz meu pai, porque foi escola de polícia na ditadura, lembra que estudamos no colégio?

- Como assim, mataram gente lá?

- Meu pai diz que não, que Elena se aflige à toa, que ali foi escola de polícia, nada mais. (ENRÍQUEZ, 2017, p. 37, grifos nossos).

Elena é a força de silenciamento social que se impõe contra o avivamento da memória do local traumático. A princípio, nem o narrador, nem o diálogo entre as personagens, conduzem à certeza de que na hospedaria foi cometida alguma violência, a não ser o que uma escola de polícia traz em si enquanto símbolo de tortura no cenário argentino. Da simples menção à escola de polícia, pode emergir "uma memória coletiva subterrânea da sociedade civil dominada ou de grupos específicos, de uma memória coletiva organizada que resume a imagem que uma sociedade majoritária ou o Estado desejam passar e impor" (POLLAK, 1989, p. 8). Elena foi além: impediu que o pai de Rocío voltasse a trabalhar com turismo e o perseguiu financeiramente até que ele decidiu que se mudaria da cidade. Eis uma representação de como a ditadura conduz ao silenciamento pelo exílio. Assim, Elena também representa o Estado.

Mas Rocío estava com muita raiva. Plena daquela audácia adolescente e da vontade de justiça, pôs em prática, junto com Florência, um plano para acabar com a hospedaria: colocar bifes escondidos nos colchões dos quartos, e arrumar as camas. Ninguém iria descobrir. Quando apodrecessem, o cheiro decrépito que sairia dos quartos tomaria o lugar por uma podridão tão absoluta que afastaria os hóspedes para sempre. O plano de vingança contra Elena era perfeito.

Rocío abriu a mochila que havia carregado por todo o caminho até a praça e lhe mostrou o conteúdo, que sob a luz do poste fez Florência saltar: pareceulhe um animal morto, um pedaço de corpo humano, algo macabro. Mas 
não: eram bifes de contrafilé. (ENRÍQUEZ, 2017, p. 39, grifos nossos).

Florência reage à carne com espanto, porque, em seu olhar, a carne ganha uma imediata subjetividade. A noite, a luz do poste e a clandestinidade do encontro a faz associar o que está vendo a perigo e por isso transforma a carne em outra coisa. Sua reação provém de um olhar carregado de morbidez. A carne é uma metonímia para o corpo morto. E aqui começa a se desenhar a atmosfera macabra que o conto adquire mais adiante. Depois, recupera-se, pois é o que se espera do contato com a morte. Seguem o plano.

$\mathrm{O}$ prédio trazia na arquitetura a imagem de uma marca histórica: "O formato da hospedaria era estranho e, de fato, lembrava muito um quartel” (ENRÍQUEZ, 2017, p. 40). À medida que entravam, a escuridão da noite conduzia Florência a um medo brutal. Tudo parecia fantasmagórico. A hospedaria tinha uma aura de terror que ela sentiu imediatamente. Essa aura do local traumático, que na narrativa se fixa no imaginário da personagem, é construída simbólica e historicamente: "o vínculo peculiar entre proximidade e distância confere aura a esses locais e neles se procura um contato direto com o passado" (ASSMANN, 2011, p. 359). Mas algo realmente terrível aconteceu com Florência e Rocío depois de executarem seu plano. Logo após distribuírem os bifes, antes mesmo de elaborar uma sensação de entusiasmo pelo dever cumprido, ainda no prédio, foram surpreendidas por um barulho de motor vindo de fora da hospedaria.

E depois mais um motor, e então alguém começou a bater com algo metálico nas persianas e as duas se abraçaram na escuridão gritando, porque aos motores e às pancadas nas janelas se juntaram corridas de muitos pés ao redor da hospedaria e gritos de homens; e os homens que corriam agora batiam em todas as janelas e as persianas, e iluminavam com faróis do caminhão ou caminhonete ou carro o quarto onde elas estavam, por entre as frestas da persiana podiam ver os faróis, o carro estava subindo o jardim e os pés continuavam correndo e as mãos batendo e algo metálico também batia e havia gritos de homem, muitos gritos de homem; alguém dizia: "Vamos, vamos", escutou-se um vidro quebrado e mais gritos. Florência sentiu que se urinava, não pôde se conter, não pôde, e não conseguia mais gritar porque o medo não a deixava respirar. (ENRÍQUEZ, 2017, p. 42, grifos nossos).

Para Halbwacks, "quando dizemos que a recordação de certas lembranças não depende da nossa vontade, é porque a nossa vontade não é forte o suficiente” (2003, p. 59). Por vezes, a vontade não é forte o suficiente para silenciar a lembrança. Ainda que não desejemos, ela se manifesta. Nesse trecho, temos o ponto-chave de tensão da narrativa, que se desenrolava de maneira fluida até então. O equilíbrio é interrompido no momento em que a lembrança 
fantasma aponta para o passado de violência que a hospedaria abriga como símbolo do silenciamento do local. Mais uma vez, o passado traumático é apenas subentendido, porque a memória de terror é captada pelo imaginário das personagens. Ninguém ouviu grito algum, apenas Florência e Rocío. Mas havia gritos, gritos de homens, muitos gritos de homens, gritos desumanos. O que isso significava? Elas não tinham como compreender, porque a incompreensão e o esgotamento das palavras são inerentes ao trauma.

Ao ouvir tantos gritos, também gritaram, em estado de pânico. O lugar em que se encontravam era a hospedaria, mas também não era mais. Então, que lugar era esse? Onde estavam? O que faziam ali? Quem eram aqueles homens? No estado de pânico só há dúvidas e nenhuma explicação. No estado de pânico não há como elaborar nenhuma resposta, porque sequer as perguntas fazem algum sentido e porque isso exige uma imersão em si mesmo. Ainda assim, o pânico é a completa saída do sujeito para fora de si. Nesse estado de total ruptura entre as coisas e os sentidos que elas podem ter, Florência e Rocío são encontradas por Elena, a dona da hospedaria. Questionadas, tentam descrever o que viram e ouviram: os carros, os faróis, pancadas na janela. Mas Elena fica irritada. Sem compreender o porquê de tanta confusão, reage desacreditando o que ouviu e elabora sua própria verdade sobre os fatos, que só poderia ser a verdade verdadeira: "a fedelha estava mentindo, inventando aquela história de fantasmas para arruinar a hospedaria assim como Mário desejara arruiná-la; ela a traía como Mário, com certeza por ordem dele" (ENRÍQUEZ, 2017, p. 43).

Rocío, a quem Elena estava desautorizando, representa os grupos de resistência ao Estado, acusados de subversivos. Toda a lógica da vingança de Rocío é uma retomada dessas relações de poder dos regimes ditatoriais. Alguém é punido (seu pai), daí instala-se um cenário no qual a informação passa a ser censurada - ele relatou o que houve na hospedaria e foi demitido -, quem subverte a ordem da censura é perseguido - seu pai é forçado a mudar de cidade; foi exilado -, um levante estratégico precisou ser organizado para retomar a reivindicação por direitos e a liberdade tomada de assalto pelo Estado (a vingança).

Florência simboliza o corpo torturado. Urina, terror, paralisia diante da violência eram respostas comuns à dor e ao choque da tortura, assim como o silêncio da vítima. Florência não soube lidar com o terror repentino, como não o saberia também a vítima sequestrada pela ditadura na calada da noite, porque "o dado imaginável da experiência concentracionária desconstrói o maquinário da linguagem" (SELIGMANN-SILVA, p. 2003, 47). Por isso, de nada adiantaria testemunhar o que viveu. Como provar o que ninguém mais viu? Interpelada pela irmã, Lali, já em casa, em sua cama, ela desiste de qualquer tentativa de explicação e, como Rubinho de Veríssimo, decide calar-se. "Me deixa" é só o que consegue dizer. Não 
acertou elaborar uma explicação digna de crédito, porque nada sairia de seu testemunho como verdade. Ela sabia que seu grito desumano nunca a faria ser escutada.

\section{MESMO CALADO O PEITO, RESTA A CUCA}

“Cale-se!" é o que dizem forças de silenciamento construídas historicamente. Mas ainda que estejam caladas as emoções, resta a consciência. Na letra de Chico e Gil (1978), uma voz se enuncia: "Quero inventar o meu próprio pecado, quero morrer do meu próprio veneno". De quem é essa voz? Quem a faz beber do cálice que transborda com seu próprio sangue? Para Seligmann-Silva, só a arte pode desafiar a intraduzibilidade do "real" (2003, p. 47). Por isso, a leitura estética do passado pode apresentar e expor suas feridas. Por isso, a arte é uma potência narrativa capaz de dizer o indizível. A voz que clama por justiça e liberdade em "Cálice" é a voz de muitos. E faz reacender a memória subterrânea suplantada pelo silenciamento toda vez que toca a canção. A memória acerca dos locais traumáticos é uma construção histórica em que concorrem a lembrança e o silenciamento como forças retóricas, que se apresentam potencialmente nas mais diversas práticas discursivas, mas têm nas narrativas artísticas um território muito mais amplo para elaborar-se como verdade. Isso porque o fazer estético da literatura faz representar subjetividades e reelaborar o real como mais liberdade de dizer o que foi, mesmo que decida não dizer. A literatura não se dobra ao real, ela o determina. Literatura é resistência não porque o real não a alcança, mas porque é nela que ele se subverte em si mesmo. Na literatura, o real não tem compromisso com a verdade. E não tendo, torna-se verdade.

Para Alfredo Bosi, a narrativa de natureza resistente é aquela que "decorre de um $a$ priori ético, um sentimento do bem e do mal, uma intuição do verdadeiro e do falso, que já se pôs em tensão com o estilo e a mentalidade dominantes" (BOSI, 1996, p. 22, grifo do autor). O ético elucidado pelo fazer estético é, em verdade, inerente ao próprio narrar literário. Porque a literatura, enquanto arte, diz o indizível, e enquanto voz não se cala e não se submete a forças de silenciamento que se impõem contra os coletivos de pensamento. A narrativa literária é uma potência de inscrição da violência na história de um grupo. E a memória, mais que um bem comum, é "uma necessidade jurídica, moral e política. (SARLO, 2007, p. 47)". Literatura, portanto, é resistência por ser escrita de todas as maneiras que o sujeito encontra de resistir àquilo que tenta aniquilar sua identidade.

Veríssimo e Enríquez traduzem o intraduzível da memória traumática que, na disputa entre lembrança e esquecimento, perdura e se ressignifica todas as vezes que incorpora uma 
voz no mundo narrado. Jesus, Rogério, Rubinho, Florência, Rocío. Com quantos nomes o corpo torturado pela ditadura vai ressurgir na literatura? Para Sarlo, "A narração também funda uma temporalidade, que a cada repetição e a cada variante torna a se atualizar" (SARLO, 2007, p. 25). Assim, se literatura é resistência, a resposta para essa pergunta é: quantas vezes forem necessárias. A narração da violência é uma força que se opõe a outra força. Por essa razão, para Bosi (1996), a resistência é imanente ao narrar. É uma luta contra o esquecimento. E uma luta necessária, "porque não só a tendência a esquecer é forte, mas também a vontade, o desejo de esquecer" (GAGNEBIN, 2006, p. 101).

Veríssimo, Enríquez, Brasil, Argentina, um prédio abandonado, uma hospedaria. A linha condutora desses narrares é a resistência. O que há no entrecruzamento de suas palavras, de suas vozes enquanto narradores, é o cálice de sangue que beberam na história de violência de seus países. Suas narrativas representam a experiência de inúmeras vozes silenciadas, mas também suas próprias experiências enquanto narradores. Suas vozes. Segundo Benjamin, “o narrador retira o que ele conta da experiência: da sua própria experiência ou da relatada por outros. E incorpora, por sua vez, as coisas narradas à experiência dos seus ouvintes" (BENJAMIN, 1994, p. 217). Assim, Veríssimo e Enríquez testemunham. E entre todas as possibilidades que a arte lhes proporciona em seu fazer estético, fazem a escolha pelo não calar, afinal, calar é censurar a si mesmo. E não há resistência mais ofensiva à censura do que a arte.

\section{REFERÊNCIAS}

ASSMANN, Aleida. Espaços da recordação: formas e transformações da memória cultural. Trad. Paulo Soethe. Campinas: Editora da Unicamp, 2011.

BENJAMIN, Walter. O narrador: considerações sobre a obra de Nikolai Leskov. In. Magia, técnica, arte e política. São Paulo: Brasiliense, 1994.

BOSI, Alfredo. Narrativa e Resistência. In: Revista Itinerários. São Paulo: USP, 1996. Disponível em: https://periodicos.fclar.unesp.br/itinerarios/article/viewFile/2577/2207. Acesso em: 01 ago. 2019.

BUARQUE, Chico; GIL, Gilberto. Cálice. BUARQUE, Chico. Chico Buarque. Rio de Janeiro: Polygram/Philips, v. 1, 1978.

ENRÍQUEZ, Mariana. A hospedaria. In: ENRÍQUEZ, Mariana. As coisas que perdemos no fogo. Trad. José Geraldo Couto. Rio de Janeiro: Intrínseca, 2017.

GAGNEBIN, Jean Marie. Lembrar, escrever, esquecer. São Paulo: Editora 34, 2006. 
HALBWACHS, Maurice. A memória coletiva. Trad. Beatriz Sidou. São Paulo: Centauro, 2003.

POLLAK, Michel. Memória, esquecimento, silêncio. In: Estudos Históricos. Rio de Janeiro, Vol. 2. n. 1, 1989.

SARLO, Beatriz. Tempo passado: cultura da memória e guinada subjetiva. Trad. Rosa Freire Aguiar. São Paulo: Companhia das Letras; Belo Horizonte: UFMG, 2007.

SARMENTO-PANTOJA, Augusto. Quando resistir não basta. In: Revista Moara. Ed. 44. 2015. Disponível em: https://periodicos.ufpa.br/index.php/moara/article/view/3433. Acesso em: 01 ago. 2019.

SELIGMANN-SILVA, Márcio. Apresentação da questão: a literatura do trauma. In: SELIGMANN-SILVA, Márcio (org.) História, Memória, Literatura: o testemunho na era das catástrofes. Campinas - SP: Editora da Unicamp, 2003.

VERÍSSIMO, Luís Fernando. A mancha. São Paulo: Companhia das Letras, 2004.

Recebido: $23 / 04 / 2020$

Aprovado: $28 / 07 / 2020$ 